\title{
Understanding the adsorption of plasmid DNA and RNA molecules onto arginine-agarose chromatographic resin
}

\author{
Sara Cardoso ${ }^{1} \cdot$ Fani Sousa $^{2} \cdot$ Pedro A. Pessoa Filho $^{1} \cdot$ Adriano R. Azzoni $^{1}$ (]
}

Received: 24 August 2021 / Accepted: 8 February 2022 / Published online: 18 February 2022

(c) The Author(s), under exclusive licence to Springer Nature B.V. 2022

\begin{abstract}
Background The production of nucleic acids (plasmid DNA or mRNA) in response to the development of new advanced vaccine platforms has greatly increased recently, mostly resulting from the pandemic situation. Due to the intended pharmaceutical use, nucleic acids preparations must fulfill all the required specifications in terms of purity and quality. Chromatography is a standard operation used to isolate these molecules from impurities, playing a central role in the manufacturing processes. However, the mechanism of nucleic acid adsorption in chromatographic resins is poorly understood, often leading to low adsorption capacities and a lack of specificity.

Methods and results Here we investigated the adsorption of plasmid DNA and RNA molecules onto arginine-agarose, a resin with potential for large-scale application. Equilibrium batch studies were performed through pre-purified samples, using arginine-based ligands by varying the adsorption conditions in the $\mathrm{pH}$ value range from 6.0 to 9.0. Langmuir and Freundlich isotherm models were used to describe the adsorption equilibrium. The best fit for both nucleic acids was achieved using the Freundlich model. The correct choice of $\mathrm{pH}$ showed critical for controlling the efficacy of arginine-nucleic acid interaction, due to its influence on the nucleic acid structures. This type of analysis is necessary for the improvement of the selectivity and binding capacities of the resins used for plasmid DNA or mRNA purification.

Conclusions The results presented here indicate that adsorption conditions can be tuned to enhance separation between pDNA and RNA, an important feature in the purification of nucleic acids for vaccine production.
\end{abstract}

Keywords Adsorption $\cdot$ Batch equilibrium $\cdot$ Plasmid DNA $\cdot$ RNA $\cdot$ Arginine-agarose resin

\section{Introduction}

The increasing amounts of pharmaceutical-grade nucleic acids required to produce approved or prototype advanced mRNA or DNA vaccines against SARS-CoV-2 [1-3] demand new developments and downstream processing solutions [4-6]. Any successful mRNA or plasmid DNA (pDNA) production process should meet specific requirements: besides purity (low levels of impurities), the nucleic acids should be homogeneous, in their active form [7, 8].

Adriano R. Azzoni

adriano.azzoni@usp.br

1 Departamento de Engenharia Química, Escola Politécnica da Universidade de São Paulo, Av. Prof. Luciano Gualberto, Trav. 3, No 380, São Paulo, SP CEP 05508-900, Brazil

2 CICS-UBI - Centro de Investigação de Ciências da Saúde, Universidade da Beira Interior, Av. Infante D. Henrique, 6200-506 Covilhã, Portugal
Hence, the development of efficient production and purification processes should take into consideration cost-effectiveness and scalability, maximizing the recovery and purity, and especially preserving the structural integrity of nucleic acids [9-12].

Messenger RNA vaccines have recently demonstrated high efficacy at preventing Covid-19 illness [1, 2], and are currently being used globally. The mRNA vaccine has several advantages over traditional vaccines, due to its flexibility and efficiency in immunogen design and manufacturing [2]. Messenger RNA molecules are synthesized from linearized pDNA by an in vitro transcription reaction. Besides the plasmid DNA template, this reaction requires nucleotides, polymerase, and capping enzymes, from which the mRNA product should be properly purified by chromatographic operations. The optimization of the purification strategy is seen as one of the main achievements leading to the reduction of innate sensing and increasing the efficiency of the mRNA vaccine prototypes [13]. 
Plasmid DNA molecules, however, are commonly produced in bacterial host cells. Plasmids typically represent less than $3 \%$ of the macromolecules present in cell lysates of Escherichia coli (E. coli) strains [14]. Recovery and purification processes commonly start with alkaline lysis that removes part of the cell walls, proteins, and genomic DNA (gDNA), and proceed to further purification usually using chromatographic steps $[15,16]$. At this point, low molecular weight host RNA is perhaps the most critical impurity, mainly due to its considerable amount and physical-chemical properties similar to pDNA [10, 15, 17]. As an example, the negatively charged RNA molecules are frequently expected to present similar adsorption patterns when interacting with cationic ligands of chromatographic resins. These similarities make RNA likely to compete and to co-purify with plasmid DNA in several unit operations $[10,16,18]$. Our group has recently presented a new approach for pDNA purification using an agarose support. This work showed that negative mode chromatography, using a traditional arginine-based agarose resin, can promote high pDNA recovery and purification, comparable with monolithic resins, with an efficient separation from host RNA [19]. Although this strategy represents an interesting alternative to previously developed pDNA purification methods, with potentially lower operating costs, the mechanisms behind the adsorption of pDNA and RNA on arginine-based resins remain not completely understood. Through relatively simple batch format studies, important biomolecule-adsorbent parameters, essential to the development of adsorption processes, can be determined to elucidate some of these aspects [20, 21]. In special, adsorption $\mathrm{pH}$ is one of the critical points to consider when choosing the process conditions for adsorption with an impact on the adsorption capacity and selectivity of chromatographic supports [22-24]. The comparison of isothermal profiles determined in buffers with different $\mathrm{pH}$ values allows identifying even small differences in the adsorption mechanisms of pDNA and RNA in a chosen resin, permitting the use of adequate process conditions to better separate the target pDNA molecule. It is thus possible to control and to optimize selectivity and process yield by choosing the correct adsorption $\mathrm{pH}[23,25]$.

The adsorption isotherm describes the relationship between the equilibrium concentration of a biomolecule in a liquid phase and the amount adsorbed in a solid phase at a given temperature [26]. Batch studies can thus provide thermodynamic information on the biomolecule-resin interaction, allowing the screening of a wide range of conditions with small amounts of product. Adsorption isotherm models, such as Langmuir and Freundlich, are widely used for modeling the adsorption of biomolecules onto chromatographic resins utilized in the development of purification processes $[20,27]$.
This work describes a systematic study on the adsorption of plasmid DNA and RNA in arginine-agarose resin using different $\mathrm{pH}$ adsorption conditions. The choice of argininebased ligands for nucleic acids purification was based on its specific interaction with these molecules, especially with supercoiled pDNA [12, 13, 28]. Here, by performing studies in a batch equilibrium format, it was possible to compare and to gather important information about the mechanisms involved in pDNA and RNA adsorption. This study also contributes to a better understanding on how structural changes in terms of hydrodynamic size, promoted by $\mathrm{pH}$ in these biomolecules, can ultimately lead to differences in adsorption selectivity and binding capacity. All together, the results indicate that adsorption conditions can be tuned to enhance separation between pDNA and RNA, an important feature in the purification of nucleic acids for vaccine production.

\section{Materials and methods}

\section{Bacterial growth and plasmid DNA/RNA isolation}

The Escherichia coli DH10b harboring the plasmid pVAX1GFP (3697 bp) [29] used in this work was kindly donated by Professor Duarte Miguel Prazeres, from Institute for Bioengineering and Biosciences (IBB), Instituto Superior Técnico, Lisbon. Pre-purified plasmid DNA production was performed growing Escherichia coli DH10B in $1 \mathrm{~L}$ shake flasks containing $250 \mathrm{~mL}$ of terrific broth medium $(10 \mathrm{~g} / \mathrm{L}$ of bactotryptone, $5 \mathrm{~g} / \mathrm{L}$ of yeast extract and $10 \mathrm{~g} / \mathrm{L}$ of sodium chloride) supplemented with $30 \mu \mathrm{g} / \mathrm{mL}$ of kanamycin. Cultivation was performed at $37^{\circ} \mathrm{C}$, under $250 \mathrm{rpm}$. The growth was controlled by measuring the $\mathrm{OD}_{600 \mathrm{~nm}}$ and was finalized at the late exponential phase. Cells were recovered by centrifugation, at $4500 \times g$ for $30 \mathrm{~min}$ at $4{ }^{\circ} \mathrm{C}$ and the pellet was frozen at $-20{ }^{\circ} \mathrm{C}$ until further use. The plasmids were obtained by alkaline lysis using the Illustra plasmid Prep Midi Flow Kit (GE Healthcare, USA), according to the manufacturer's instructions. In the case of RNA purification, the same non-carrying plasmid E. coli strain was used. After the bacterial growth, the cells were collected (as previously described) and purified according to the protocol described by Neto (2018) [30]. Two hundred milligrams of bacterial cell pellet were resuspended in $30 \mu \mathrm{L}$ of DEPC, $797 \mu \mathrm{L}$ of solution containing spermidine $(5 \mathrm{mM}$ spermidine in $20 \mathrm{mM}$ Bis-Tris propane at $\mathrm{pH}$ 6.9) and $206 \mu \mathrm{L}$ EDTA solution $(500 \mathrm{mM})$. The homogenate was transferred to polypropylene tubes compatible with Fast Prep equipment (Savant FP120 - Thermo Fischer Scientific, USA), containing $0.5 \mathrm{~g}$ of $0.2 \mathrm{~mm}$ diameter glass spheres treated with $0.1 \%$ DEPC. The cells were disrupted in a bead-beater equipment for three cycles of $45 \mathrm{~s}$ at 4,500 rpm. Immediately after lysis, the tube was cooled on ice for $1 \mathrm{~min}$. The 
sample was centrifuged at $10,000 \times g, 4{ }^{\circ} \mathrm{C}$, for $10 \mathrm{~min}$. The supernatant was collected and divided into equal portions for $2 \mathrm{ml}$ polypropylene tubes. In each tube, $1 \mathrm{ml}$ of Trizol (TRI Reagent, Invitrogen Life Technologies, USA) was added. The tubes were vortexed vigorously for $2 \mathrm{~min}$ and heated to $65^{\circ} \mathrm{C}$ for $10 \mathrm{~min}$. Subsequently, $400 \mu \mathrm{L}$ of chloroform was added to each tube and stirred vigorously. The samples were centrifuged $\left(18,000 \times g, 4^{\circ} \mathrm{C}, 5 \mathrm{~min}\right)$. Then, the aqueous phase (containing the RNA) was carefully removed to preserve the intermediate and bottom phases. The same volume of isopropanol was added, and the tubes were inverted manually a few times for complete homogenization. The mixture was kept on the bench for about $10 \mathrm{~min}$. After this period, the sample was centrifuged $\left(18,000 \times g, 4{ }^{\circ} \mathrm{C}, 5 \mathrm{~min}\right)$ and the supernatant was discarded with the aid of the pipette. Then, $500 \mu \mathrm{L}$ of $70 \%$ alcohol was added to the precipitate to remove salts. RNA suspension was smoothly homogenized and centrifuged at $18,000 \times g, 4^{\circ} \mathrm{C}$, for $5 \mathrm{~min}$. The tube containing the precipitate was upturned in a paper tissue for approximately 3 min for drying. Finally, the RNA precipitate was suspended in buffer and used in the following studies. Possible protein contamination in pDNA or RNA samples was verified via A260/A280 absorbance ratio. Since values of approximately 1.85 (for pDNA) or 2.0 (for RNA) were obtained, the samples were assumed as sufficiently free of protein impurities. The integrities of the purified pDNA and RNA were confirmed by $0.8 \%$ agarose gel electrophoresis.

\section{Immobilization of arginine ligands on agarose resins}

The arginine chromatographic supports were prepared as described previously [19] by immobilizing the arginine (Sigma-Aldrich, USA) in a pre-activated agarose medium (Epoxy-activated Sepharose 6B, GE Healthcare, USA), following manufacturer's instructions. Arginine ligands were diluted in a suitable coupling solution $(0.5 \mathrm{M}$ carbonate buffer $\mathrm{pH} 9.5$ ) to a final concentration of $100 \mu \mathrm{M}$ arginine/ $\mathrm{mL}$. The immobilization procedure consisted of mixing the arginine solution through the pre-activated medium (in a ratio of 1:1), followed by 16 -h incubation at $25{ }^{\circ} \mathrm{C}$. After this, several washes were performed with the coupling buffer, and the remaining epoxy-groups were blocked by soaking a $0.1 \mathrm{M}$ Tris- $\mathrm{HCl} \mathrm{pH} 8.0$ buffer for $4 \mathrm{~h}$, at $45{ }^{\circ} \mathrm{C}$. Finally, for group activation, the product was washed thoroughly with 3 cycles of 2 different solutions with alternating $\mathrm{pH}(0.1 \mathrm{M}$ acetate $\mathrm{pH} 4.0$ containing $0.5 \mathrm{M} \mathrm{NaCl} ; 0.1 \mathrm{M}$ Tris- $\mathrm{HCl} \mathrm{pH} 8.0$ containing $0.5 \mathrm{M} \mathrm{NaCl}$ ). The SEM-EDX technique was used to provide the elemental identification and qualitative compositional information of the resin before and after the immobilization of the arginine, as an evidence of the effective immobilization of the ligand in the pre-activated resin [19].

\section{Determination of adsorption isotherms}

Pre-purified plasmid and RNA solutions of known concentration were prepared in $20 \mathrm{mM}$ Tris and $10 \mathrm{mM}$ EDTA buffer, at different $\mathrm{pH}$ values $(6.0 ; 7.0 ; 8.0$ and 9.0), and the samples were successively diluted. Each sample solution $(0.5 \mathrm{~mL})$ was placed in contact with $25 \mu \mathrm{L}$ of resin in $2 \mathrm{~mL}$ Eppendorf tube. The mixtures were incubated for over $24 \mathrm{~h}$ at $25^{\circ} \mathrm{C}$ and with constant mixing in a circular blood homogenizer to allow the equilibrium to be reached. The equilibrium concentrations were determined by absorbance at $260 \mathrm{~nm}$ (1 unit of absorbance being equivalent to $50 \mu \mathrm{g} /$ $\mathrm{mL}$ pDNA or $40 \mu \mathrm{g} / \mathrm{mL} \mathrm{RNA}$, for an optical path of $1 \mathrm{~cm}$ ). The amount of adsorbed pDNA and RNA was calculated by mass balance to the solution, before and after equilibration. Previously to the adsorption equilibrium determination, adsorption kinetics was assessed. At each pH, $0.5 \mathrm{~mL}$ of solutions with different initial concentrations of pDNA $(160 \mu \mathrm{g} / \mathrm{mL}, 80 \mu \mathrm{g} / \mathrm{mL}$, and $40 \mu \mathrm{g} / \mathrm{mL})$ were contacted with $25 \mu \mathrm{L}$ of resin, and the supernatant concentration was determined at specific intervals. Adsorption occurs mainly in the first $10 \mathrm{~min}$, and equilibrium is reached in about $60 \mathrm{~min}$ (data not shown). Therefore, the total experiment time of $24 \mathrm{~h}$ is sufficient to assure that equilibrium is obtained. Due to the extended $\mathrm{pH}$ range (from 6.0 to 9.0) studied in this work using the Tris buffer, previous adsorption studies were performed measuring the initial and final $\mathrm{pH}$ of the adsorption samples in order to verify the stability of the $\mathrm{pH}$ during the experiments. No significant changes in the $\mathrm{pH}$ of the samples were found.

The Langmuir (Eq. 1) and Freundlich (Eq. 2) models were fit to the adsorption experimental data.

$q=q_{\max } K_{A} \frac{C}{1+K_{A} C}$

$q=K_{f} C^{\frac{1}{n}}$

where $C$ is the biomolecule equilibrium concentration in solution, $q$ is the biomolecule solid-phase equilibrium concentration. The maximum binding capacity $\left(q_{\max }\right)$, the association constant $\left(K_{A}\right)$, and the Freundlich constants $\left(K_{F}\right.$ and $n$ ) were obtained from the best fit of the isotherms to the experimental data for each set of conditions tested. This procedure was performed using Levenberg-Marquardt and Orthogonal Distance regression routines, for the Langmuir and Freundlich models, respectively, implemented in the program Origin version 8.0 (Origin Lab, USA).

\section{Determination of hydrodynamic size}

The size distribution was measured by DLS (Dynamic Light Scattering) in undiluted samples in $1 \mathrm{~mL}$ volume 
cuvettes at $25^{\circ} \mathrm{C}$ using a Zeta Plus - Zeta Potential Analyzer (Brookhaven Instruments $\mathrm{Co}, \mathrm{UK}$ ) equipped with a $633 \mathrm{~nm}$ laser and $173^{\circ}$ detection optics. For data acquisition and analysis, the software Malvern DTS v.5.10 (Malvern Instruments) was used. A standard polystyrene cuvette, with a square cross section of $1 \mathrm{~cm} \times 1 \mathrm{~cm}$, was used. The sample volume required for the measurement was $1.5 \mathrm{~mL}$. Measurements were made in duplicate from final sample concentrations of 100 and $200 \mu \mathrm{g} /$ $\mathrm{mL}$, respectively, for pDNA and RNA. The equilibrium time was the standard given by the machine measurement method, which records a measure after a stable number of measurements.
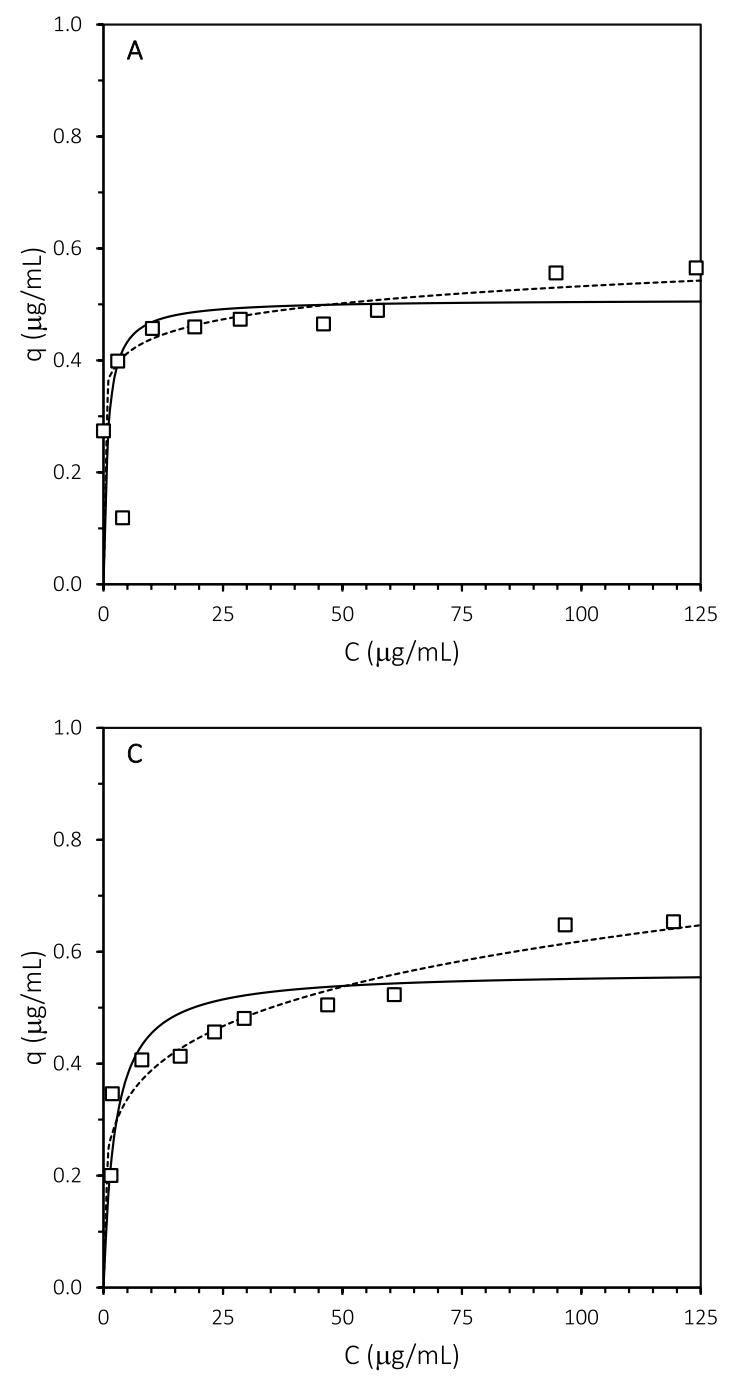

Fig. 1 Adsorption isotherms for the adsorption of plasmid DNA onto arginine-agarose resin at different $\mathrm{pH}$ values. Adsorption occurred in $20 \mathrm{mM}$ Tris buffer containing $10 \mathrm{mM}$ EDTA at $\mathrm{pH} 6.0$ (A), $\mathrm{pH} 7.0$

\section{Results and discussion}

\section{Adsorption isotherms of plasmid DNA and RNA on arginine-agarose resin}

The experimental results on the equilibrium isotherms of pDNA and RNA are presented in Fig. 1 (pDNA) and Fig. 2 (RNA); in both Figures, the correlation of the experimental data with the Langumir and Freundlich equations is also presented. In general, the experimental curves are characterized by a sharp increase in the concentration of adsorbed molecules as the concentration in the solution increases, followed by a plateau at higher concentrations, especially in the case of pDNA. Those isotherms are considered favorable,
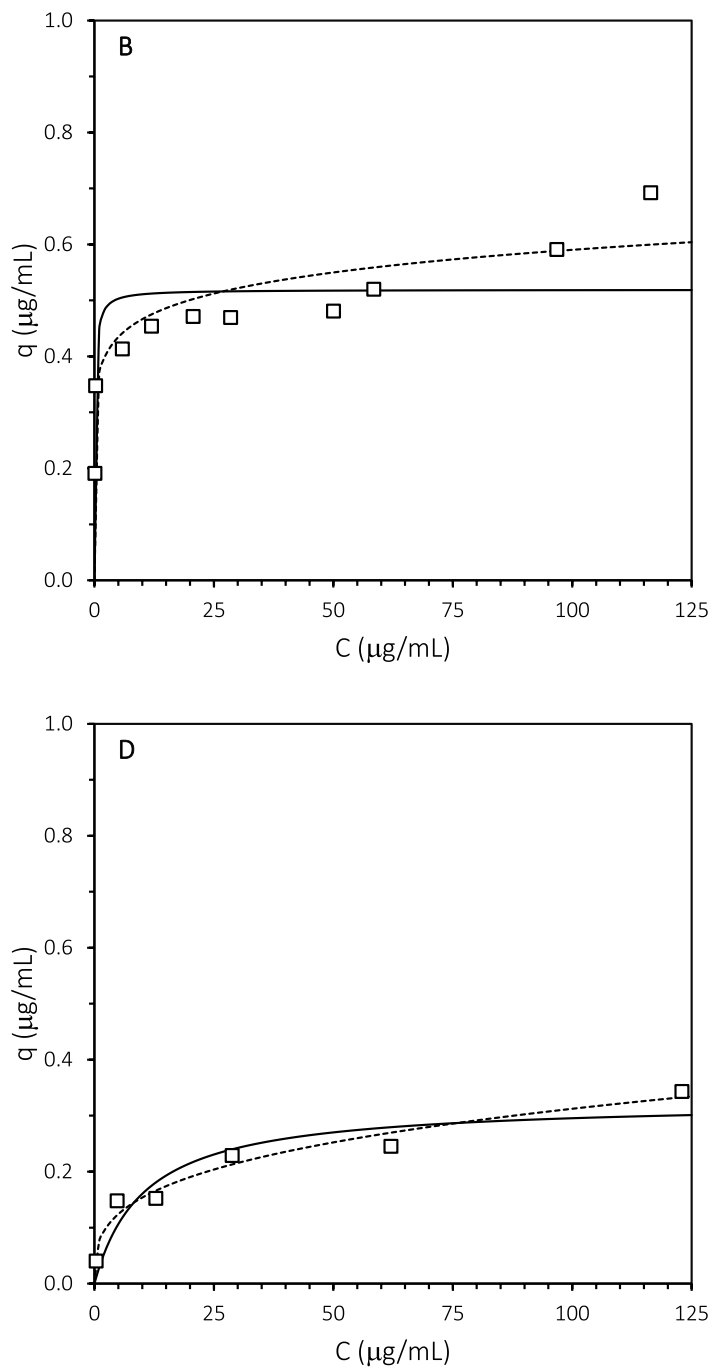

(B), $\mathrm{pH} 8.0$ (C) and $\mathrm{pH} 9.0$ (D) and the corresponding adjustment with the Langmuir (continuous line) and Freundlich (dashed line) models 

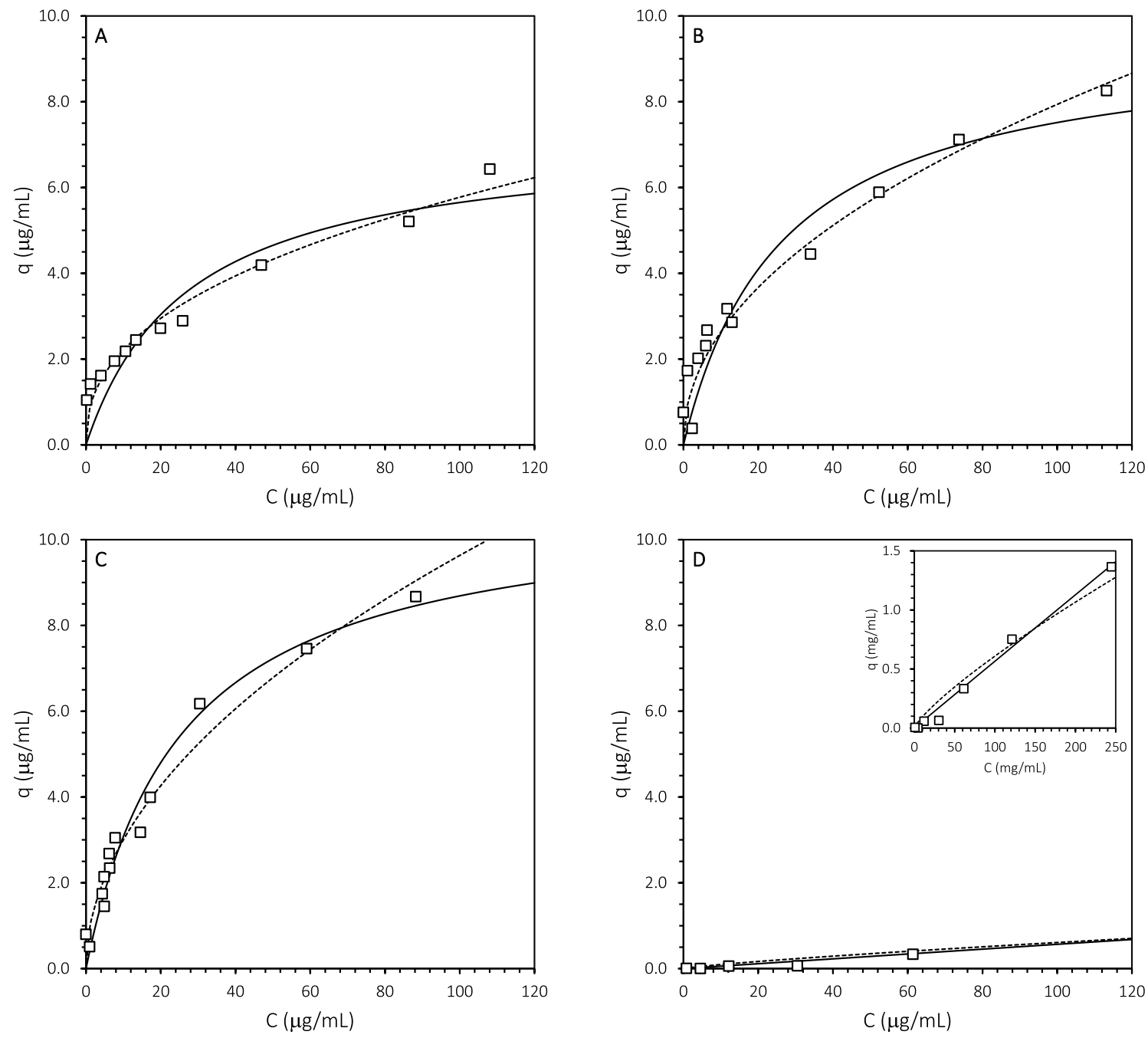

Fig. 2 Adsorption isotherms for the adsorption of RNA onto arginine-agarose resin at different $\mathrm{pH}$ values. Adsorption occurred in $20 \mathrm{mM}$ Tris buffer containing $10 \mathrm{mM}$ EDTA at $\mathrm{pH} 6.0$ (A), $\mathrm{pH} 7.0$

since they present a nonlinear and concave slope in relation to the abscissa axis [31].

Favorable isotherms usually permit higher resin adsorption capacities at lower solution concentrations compared with linear or unfavorable isotherms. Moreover, unfavorable or linear isotherms tend to be associated with broad breakthrough-curves when adsorption occurs in packed bed columns, due to the higher axial dispersion [32].

Experimental adsorption isotherm datasets were fitted through non-linear regression to the non-linear forms of the Langmuir (Eq. 1) and Freundlich (Eq. 2) models. The nonlinear regression was used to avoid possible biases related to linearization [33]. For pDNA and RNA adsorption curves, both Langmuir and Freundlich models resulted in a good adjustment to the experimental data, and the Freundlich model presents a slightly better fitting.

(B), $\mathrm{pH} 8.0$ (C) and $\mathrm{pH} 9.0$ (D) and the corresponding adjustment with Langmuir (continuous line) and Freundlich (dashed line) models. The insert in $\mathbf{D}$ shows the same data with different axis limits

The Langmuir model assumes monolayer adsorption process on a surface, which contains a finite number of adsorption sites, admitting no adsorbate "migration" along the surface. Its parameters are the maximum value for adsorption capacity per unit of adsorbent mass or volume, $q_{\max }$, and the Langmuir constant, $K_{A}$, which indicates the affinity of the solute by the adsorbent [34]. On the other hand, the Freundlich model is an empirical model that admits a multi-layer process in which the amount of adsorbed solute per unit adsorbent mass increases gradually in a non-homogeneous surface. The Freundlich model presents two parameters, $K_{f}$ and the exponent $1 / n$. According to Sposito (1980) [35], the parameter $K_{f}$, called Freundlich adsorption coefficient, is related to the adsorption of the molecule in the resin, and the value of $\mathrm{n}$ is qualitatively related to the distribution of energetic sites in the resin pores [34]. 
The values of the corresponding isotherm parameters for each $\mathrm{pH}$ range dataset are presented in Tables 1 and 2, respectively for plasmid DNA and RNA molecules. The model fitting was evaluated by determining the respective correlation coefficient $\left(\mathrm{R}^{2}\right)$ as a measure of the data precision, and the mean square weighted deviation (chi-squared statistic), to predict the goodness-of-fit.

In the case of plasmid DNA adsorption (Fig. 1), the isotherms seem to indicate that a maximum adsorption capacity is reached at high liquid-phase equilibrium concentrations, which is typical of the Langmuir model; however, a small increase in $q$ is observed at higher values of $C$. Assuming plasmids as large and coiled molecules, we can expect significant steric exclusion from the particle pores, reducing the maximum binding capacity of agarose-based resins [16]. The Langmuir model also assumes adsorbates as point objects, that bind to only one ligand on the surface [26]. Unlike proteins, which commonly have charges unequally distributed in the domains of the molecule, the distribution of charges in the pDNA tends to be more uniform throughout the molecule. Therefore, pDNA may form multipoint ionic interactions with the resin surface, shielding other ligands around, which no longer participated in the binding process of additional molecules at lower liquid-phase concentrations $[20,36]$. However, at higher concentrations, the excess of (highly) negatively charged molecules in the liquid phase may displace part of these multipoint ionic interactions, therefore allowing the adsorption of additional pDNA molecules by changing the orientation of the adsorbed molecules. This fact may explain the better fitting results presented by the Freundlich model, compared to Langmuir (Table 1), which is confirmed by the slightly higher correlation coefficient $\left(\mathrm{R}^{2}\right)$ and the smaller value of the mean square weighted deviation (chi-squared). That adsorbed pDNA molecules change orientation with surface coverage has been reported, and a similar mechanism may therefore result in the observed behavior [37].

RNA adsorption onto arginine-agarose resin is also highly dependent on the $\mathrm{pH}$ value. The larger structural variations manifested by RNA, compared to DNA, make the analysis of the adsorption of this molecule far more complex. RNA preparations from cell lysates can present highly variable size and sequence distribution, with virtually every molecule assuming a different structural shape in solution, ultimately promoting an irregular and multilayer adsorption due to nonspecific RNA-RNA interactions via base pairing. This phenomenon may help to explain the much higher adsorption capacity found for RNA onto arginine-agarose resin when compared to pDNA. The Freundlich model represented the adsorption of RNA molecules better than the Langmuir
Table 1 Langmuir and Freundlich isotherm parameters of plasmid DNA adsorption obtained by nonlinear fitting at four $\mathrm{pH}$ values using $20 \mathrm{mM}$ Tris buffer containing $10 \mathrm{mM}$ EDTA at $\mathrm{pH} 6.0,7.0,8.0$, and 9.0

Table 2 Langmuir and Freundlich isotherm parameters of $R N A$ adsorption obtained by nonlinear fitting at four $\mathrm{pH}$ values using $20 \mathrm{mM}$ Tris buffer containing $10 \mathrm{mM}$ EDTA at $\mathrm{pH}$ $6.0,7.0,8.0$, and 9.0

\begin{tabular}{llllll}
\hline Model parameter & $\mathrm{pH} 6.0$ & $\mathrm{pH} \mathrm{7.0}$ & $\mathrm{pH} 8.0$ & $\mathrm{pH} \mathrm{9.0}$ \\
\hline Langmuir & $\begin{array}{l}\mathrm{q}_{\max } \\
(\mathrm{mg} / \mathrm{mL} \text { resin })\end{array}$ & $0.509 \pm 0.047$ & $0.519 \pm 0.035$ & $0.565 \pm 0.033$ & $0.326 \pm 0.032$ \\
& $\mathrm{~K}_{\mathrm{A}}$ & $1.15 \pm 1.44$ & $6.23 \pm 4.98$ & $0.408 \pm 0.150$ & $0.097 \pm 0.038$ \\
& $(\mathrm{~mL} / \mu \mathrm{g})$ & & & \\
& $\mathrm{R}^{2}$ & 0.924 & 0.836 & 0.939 & 0.975 \\
& $\chi^{2}$ & $1.03 \times 10^{-2}$ & $8.83 \times 10^{-3}$ & $4.74 \times 10^{-3}$ & $9.60 \times 10^{-4}$ \\
Freundlich & $\mathrm{K}_{\mathrm{f}}$ & $0.356 \pm 0.013$ & $0.368 \pm 0.019$ & $0.243 \pm 0.022$ & $0.0755 \pm 0.009$ \\
& $\mathrm{n}$ & $11.3 \pm 1.24$ & $9.76 \pm 1.40$ & $4.93 \pm 0.56$ & $3.25 \pm 0.32$ \\
& $\mathrm{R}^{2}$ & 0.983 & 0.944 & 0.980 & 0.996 \\
& $\chi^{2}$ & $3.91 \times 10^{-4}$ & $1.13 \times 10^{-3}$ & $1.56 \times 10^{-3}$ & $2.89 \times 10^{-4}$ \\
\hline
\end{tabular}

\begin{tabular}{llllll}
\hline Model parameter & $\mathrm{pH} 6.0$ & $\mathrm{pH} 7.0$ & $\mathrm{pH} 8.0$ & $\mathrm{pH} \mathrm{9.0}$ \\
\hline Langmuir & $\mathrm{q}_{\max }$ & $8.88 \pm 1.12$ & $9.50 \pm 0.781$ & $10.9 \pm 0.720$ & - \\
& $(\mathrm{mg} / \mathrm{mLresin})$ & & & & \\
& $\mathrm{K}_{\mathrm{A}}$ & $0.0240 \pm 0.0075$ & $0.0379 \pm 0.0080$ & $0.0395 \pm 0.0058$ & - \\
& $(\mathrm{mL} / \mu \mathrm{g})$ & & & \\
& $\mathrm{R}^{2}$ & 0.959 & 0.982 & 0.988 & - \\
& $\chi^{2}$ & 0.479 & 0.292 & 0.184 & - \\
Freundlich & $\mathrm{K}_{\mathrm{f}}$ & $0.861 \pm 0.096$ & $0.890 \pm 0.098$ & $0.956 \pm 0.110$ & $0.00475 \pm 0.00168$ \\
& $\mathrm{n}$ & $2.42 \pm 0.165$ & $2.11 \pm 0.120$ & $2.00 \pm 0.122$ & $0.968 \pm 0.062$ \\
& $\mathrm{R}^{2}$ & 0.985 & 0.988 & 0.982 & 0.996 \\
& $\chi^{2}$ & $9.18 \times 10^{-2}$ & 0.134 & 0.197 & $2.12 \times 10^{-3}$ \\
\hline
\end{tabular}


model, due to the inexistence of monolayer adsorption, which is related to the multiple adsorption mechanisms, as explained.

The adsorption of RNA was more intensely affected by $\mathrm{pH}$ increase than adsorption of pDNA, particularly from $\mathrm{pH}$ 8.0 to 9.0. RNA is a single-stranded molecule that suffers $\mathrm{pH}$-dependent ionization of nucleobases, directly affecting its structural and functional characteristics [23, 38]. Guanosine $(\mathrm{G})$ and uridine $(\mathrm{U})$ have pKa's near 9.2, becoming anionic when deprotonated, although this $\mathrm{pKa}$ value is often perturbed in natural RNA structures. The deprotonation of $\mathrm{G}$ and $\mathrm{U}$ nucleobases at $\mathrm{pH}$ values close to 9.0 may affect RNA-RNA interactions by non-specific base pairing, avoiding multilayer adsorption onto the resin and leading to the sharp decrease in maximum binding capacity observed in Fig. 2D.

The literature describes the nature of the interaction between arginine and plasmid DNA as mixed-mode interactions. In the article published by Yusufaly et al., (2014), the salt bridge formed between a histone protein and DNA is described as a binding between the guanidinium side-chain group of the amino acid arginine and the phosphate group of the DNA backbone. This interaction was assumed as a combination of (1) electrostatic attraction between the positively charged guanidinium and the negatively charged phosphate and, (2) the formation of hydrogen bonds between the two end-group nitrogens in guanidinium and the two sidegroup oxygens on the phosphate [39]. Sousa et al. (2008) concluded that the interaction of arginine with supercoiled plasmid DNA could be electrostatic and hydrophobic, but the specific biorecognition of nucleotide bases by the arginine ligand should also be involved [40]. This interaction was also described as partly dependent on the conformation of the DNA molecule. It is then assumed in the literature that structural modifications resulting from $\mathrm{pH}$ changes may significantly affect the adsorption of nucleic acids in different ways. For this reason, the hydrodynamic sizes of the pDNA and RNA molecules at different $\mathrm{pH}$ values were measured by Dynamic Light Scattering (Table 3).

In a conventional Langmuir adsorption, some of the main restrictions for the binding capacity are the availability of ligands and the accessibility of adsorbates to these ligands in the adsorbent surface (pores) [36]. The particle sizes of epoxy-activated Sepharose 6B resin range from 45 to $165 \mu \mathrm{m}$, according to the manufacturer. The binding capacity for pDNA and RNA should depend on its average size, form, and ability to access ligands inside the particle pores. As verified in Table 3, the structure of both molecules is affected significantly by the $\mathrm{pH}$ variation. However, we observed opposite effects for $\mathrm{pH}$ increase in plasmid and RNA molecules size.

Plasmid DNA presented a small increase in hydrodynamic size in solution as $\mathrm{pH}$ increased. A possible
Table 3 Hydrodynamic size (nm) and polydispersity (PDI) values for plasmid DNA and RNA

\begin{tabular}{llllll}
\hline $\mathrm{pH}$ & $\mathrm{pDNA}$ & & & $\mathrm{RNA}$ \\
\cline { 2 - 3 } \cline { 5 - 6 } & $\begin{array}{l}\text { Hydrodynamic } \\
\text { size (nm) }\end{array}$ & $\begin{array}{l}\text { Polydisper- } \\
\text { sity (PDI) }\end{array}$ & $\begin{array}{l}\text { Hydrodynamic } \\
\text { size (nm) }\end{array}$ & $\begin{array}{l}\text { Polydisper- } \\
\text { sity (PDI) }\end{array}$ \\
\hline 6.0 & $93.6 \pm 2.83$ & 0.302 & & $311 \pm 25.7$ & 0.445 \\
7.0 & $103 \pm 3.61$ & 0.258 & & $248 \pm 16.5$ & 0.351 \\
8.0 & $111 \pm 2.97$ & 0.276 & & $195 \pm 7.80$ & 0.368 \\
9.0 & $118 \pm 6.43$ & 0.245 & & $177 \pm 18.5$ & 0.384 \\
\hline
\end{tabular}

The measurements were performed in $20 \mathrm{mM}$ Tris buffer containing 10 mM EDTA at different $\mathrm{pH}$ values ( $\mathrm{pH}$ 6.0, 7.0, 8.0 and 9.0)

explanation is the deprotonation of Tris buffer molecules (pKa of 8.1) that could be acting as counter ions in plasmid negative backbone structure, enabling condensation of the pDNA molecules. On the other hand, RNA may be affected by a different phenomenon. As a single-stranded molecule, RNA can form a variety of secondary structures, also susceptible to interact with each other by non-specific base pairing. The unexpected high average size measured by the DLS experiments may reflect this ability to interact with each other in solution, besides the natural size variation in chain length, since the RNA was directly purified from $E$. coli lysates, containing all different types of RNA. Perhaps, the use of mRNA (from in vitro transcription) instead of total RNA could provide a more homogeneous sample, with a lower polydispersion. As discussed before, $\mathrm{G}$ and $\mathrm{U}$ nucleobases of RNA are prone to deprotonation (becoming anionic) at $\mathrm{pH}$ close to 9.0, and this may affect RNA-RNA base pairing, resulting in a smaller and less polydisperse sample under DLS analysis. Overall, the DLS analysis seems to confirm that the observed decrease in pDNA and RNA adsorption on the arginine-agarose resin as the $\mathrm{pH}$ increases are possibly a result of structural changes. Particularly the adsorption of RNA seems highly dependent on its ability to self-interact, forming multiple layers on the particle surface and pores. The results presented here supports our previous work showing that RNA was preferentially bound to the arginine ligands during chromatographic purification, interfering with the binding of pDNA [19]. For this reason, the amount of plasmid processed per column volume using arginine-agarose resin, under negative mode, was substantially larger compared with the conventional positive mode. Separation of plasmid DNA from RNA molecules is a challenging task that needs to be accomplished to produce either DNA or mRNA vaccines. The results presented here add new information on the choice of adsorption $\mathrm{pH}$ to increase the separation efficiency and support the potential for the use of arginine-based resins in nucleic acid purification processes. 


\section{Conclusions}

This work focused on the study of adsorption of pDNA and RNA onto arginine-agarose resin, in batch equilibrium. Although some dispersion was observed in the experimental data around the fitted isotherms, the Freundlich model could better describe the adsorption of nucleic acids onto arginineagarose resins than the Langmuir model. The choice of $\mathrm{pH}$ was concluded to be critical for controlling the efficiency of the adsorption process. The results also showed that this parameter promoted a considerable effect on the structure of pDNA and RNA, manifested by hydrodynamic size changes and polydispersity, which can directly alter the affinity and binding capacity onto the resin. Given the lack of nucleic acids adsorption data in the literature, the results herein provide valuable information to the future development of plasmid DNA and RNA purification processes in the context of new therapies and vaccines.

Acknowledgements The authors acknowledge Professor Miguel Prazeres, from Institute for Bioengineering and Biosciences (IBB), Instituto Superior Técnico, Lisbon, for the kind donation of E. coli DH10b harboring the pVAX1-GFP plasmid, and Professor Cristiano Luis Pinto de Oliveira, Instituto de Física da Universidade de São Paulo, for the support on DLS analysis of nucleic acids.

Author contributions Ideation and design of the experiments were performed by Sara Cardoso, Fani Sousa, Pedro A. Pessoa Filho and Adriano R. Azzoni; collection of experimental data was done by Sara Cardoso; analysis of experimental data were done by Sara Cardoso, Pedro A. Pessoa Filho and Adriano R. Azzoni; Sara Cardoso drafted the core of the manuscript, whereas Fani Sousa, Pedro A. Pessoa Filho and Adriano R. Azzoni improved, edited and added to various sections of the text. All authors read and approved the final manuscript.

Funding This work was supported by $\mathrm{CNPq}$ - Conselho Nacional de Desenvolvimento Científico e Tecnológico (Grants 305747/2020-7, 444412/2014-0, 307739/2015-5 and 304125/2018-0). The authors also acknowledge the financial support of the Coordenação de Aperfeiçoamento de Pessoal de Nível Superior - Brazil (CAPES/PROEX) - Finance Code 001 . The work was also partially supported by the project PUREmiRSILs - PTDC/BII-BBF/29496/2017, funded by FEDER, through COMPETE2020 - Programa Operacional Competitividade e Internacionalização (POCI), and by national funds (OE), through FCT/ MCTES.

Data availability The authors state that all data underlying the findings are fully available without restriction. All relevant data are within the paper.

\section{Declarations}

Competing interests The authors declare no competing interests.

Ethical approval This article does not contain studies with human participants or animals. Hence, no formal consent is required.

Consent to participate Consent was obtained from all individual participants included in this study.
Consent to publish All the participants have consented to the submission of this article.

\section{References}

1. Polack FP, Thomas SJ, Kitchin N et al (2020) Safety and efficacy of the BNT162b2 mRNA Covid-19 vaccine. N Engl J Med 383(27):2603-2615. https://doi.org/10.1056/NEJMoa2034577

2. Baden LR, Sahly HME, Essink B et al (2021) Efficacy and safety of the mRNA-1273 SARS-CoV-2 vaccine. N Engl J Med 384(5):403-416. https://doi.org/10.1056/NEJMoa2035389

3. Yu J, Tostanoski LH, Peter L, Mercado NB (2020) DNA vaccine protection against SARS-CoV-2 in rhesus macaques. Science 369(6505):806-811. https://doi.org/10.1126/science.abc6284

4. Sousa A, Sousa F, Queiroz JA (2012) Advances in chromatographic supports for pharmaceutical-grade plasmid DNA purification. J Sep Sci 35:3046-3058. https://doi.org/10.1002/jssc.20120 0307

5. Schmeer M, Buchholz T, Schleef M (2017) Plasmid DNA manufacturing for indirect and direct clinical applications. Hum Gene Ther 28(10):856-861. https://doi.org/10.1089/hum.2017.159

6. Valente JFA, Sousa A, Queiroz JA, Sousa F (2019) DoE to improve supercoiled p53-pDNA purification by O-phospho-1tyrosine chromatography. J Chromatogr B 1105:184-192. https:// doi.org/10.1016/j.jchromb.2018.12.002

7. De La Vega J, Ter Braak B, Azzoni AR, Monteiro GA, Prazeres DMF (2013) Impact of plasmid quality on Lipoplex-mediated transfection. J Pharm Sci 102(11):3932-3941. https://doi.org/10. 1002/jps.23709

8. Williams JA (2013) Vector design for improved DNA vaccine efficacy, safety and production. Vaccines 1:225-249. https://doi. org/10.3390/vaccines 1030225

9. Carnes AE, Williams JA (2007) Plasmid DNA manufacturing technology. Recent Pat Biotechnol 1:151-166. https://doi.org/10. 2174/187220807780809436

10. Prazeres DMF, Monteiro GA (2014) Plasmid biopharmaceuticals. Microbiol Spectr 2:1-16. https://doi.org/10.1128/microbiolspec. PLAS-0022-2014

11. Li Y, Manzano I, Zydney AL (2019) Effects of polyamines on the ultrafiltration of plasmid DNA. Biotechnol Prog 35(2):e2765. https://doi.org/10.1002/btpr.2765

12. Almeida AM, Costa D, Simões AR, Queiroz JA, Sousa F, Sousa A (2020) Enhancement of a biotechnological platform for the purification and delivery of a human papillomavirus supercoiled plasmid DNA vaccine. New Biotechnol 59:1-9. https://doi.org/ 10.1016/j.nbt.2020.04.003

13. Jackson NAC, Kester KE, Casimiro D, Gurunathan S, DeRosa F (2020) The promise of mRNA vaccines: a biotech and industrial perspective. Nat Partners J 5(11):1-12. https://doi.org/10.1038/ s41541-020-0159-8

14. Bonturi N, Radke VSCO, Bueno SMA, Freitas S, Azzoni AR, Miranda EA (2013) Sodium citrate and potassium phosphate as alternative adsorption buffers in hydrophobic and aromatic thiophilic chromatographic purification of plasmid DNA from neutralized lysate. J Chromatogr B 919-920:67-74. https://doi.org/10. 1016/j.jchromb.2013.01.010

15. Diogo MM, Queiroz JA, Prazeres DMF (2005) Chromatography of plasmid DNA. J Chromatogr A 1069:3-22. https://doi.org/10. 1016/j.chroma.2004.09.050

16. Prazeres DMF (2011) Plasmid biopharmaceuticals: basics, applications, and manufacturing. https://doi.org/10.1002/9780470939 918 
17. Lara AR, Ramírez OT (2012) Plasmid DNA production for therapeutic applications. Methods Mol Biol 824:271-303. https://doi. org/10.1007/978-1-61779-433-9_14

18. Ferreira GN, Cabral JM, Prazeres DM (1999) Development of process flow sheets for the purification of supercoiled plasmids for gene therapy applications. Biotechnol Prog 15:725-731. https:// doi.org/10.1021/bp990065+

19. Cardoso S, de Alcântara Pessoa Filho P, Sousa F, Azzoni AR (2018) Arginine and di-arginine ligands for plasmid DNA purification using negative chromatography. Sep Purif Technol 202:281-289. https://doi.org/10.1016/j.seppur.2018.03.066

20. Ferreira GNM, Cabral JMS, Prazeres DMF (2000) Studies on the batch adsorption of plasmid DNA onto anion-exchange chromatographic supports. Biotechnol Prog 16:416-424. https://doi.org/ 10.1021/bp0000196

21. Padmavathy KS, Madhu G, Haseena PV (2016) A study on Effects of $\mathrm{pH}$, adsorbent dosage, time, initial concentration and adsorption isotherm study for the removal of hexavalent Chromium $(\mathrm{Cr}$ (VI)) from wastewater by magnetite nanoparticles. Procedia Technol 24:585-594. https://doi.org/10.1016/j.protcy.2016.05.127

22. Oliveira-Brett AM, Chiorcea AM (2003) Effect of pH and applied potential on the adsorption of DNA on highly oriented pyrolytic graphite electrodes. Atomic force microscopy surface characterisation. Electrochem Commun 5:178-183. https://doi.org/10.1016/ S1388-2481(03)00014-6

23. Goh GB, Knight JL, Brooks CL (2013) PH-dependent dynamics of complex RNA macromolecules. J Chem Theory Comput 9:935-943. https://doi.org/10.1021/ct300942z

24. Bicho D, Sousa Â, Sousa F, Queiroz J, Tomaz C (2014) Effect of chromatographic conditions and plasmid DNA size on the dynamic binding capacity of a monolithic support. J Sep Sci 37:2284-2292. https://doi.org/10.1002/jssc.201400127

25. Arkhangelsky E, Steubing B, Ben-Dov E, Kushmaro A, Gitis $\mathrm{V}$ (2008) Influence of $\mathrm{pH}$ and ionic strength on transmission of plasmid DNA through ultrafiltration membranes. Desalination 227:111-119. https://doi.org/10.1016/j.desal.2007.07.017

26. Chen X (2015) Modeling of experimental adsorption isotherm data. Inf 6:14-22. https://doi.org/10.3390/info6010014

27. Mavropoulos E, Costa AM, Costa LT, Achete CA, Mello A, Granjeiro JM, Rossi AM (2011) Adsorption and bioactivity studies of albumin onto hydroxyapatite surface. Colloids Surf B 83:1-9. https://doi.org/10.1016/j.colsurfb.2010.10.025

28. Cardoso S, Sousa A, Queiroz JA, Azzoni AR, Sousa F (2018) Arginine homopeptides for plasmid DNA purification using monolithic supports. J Chromatogr B 1087-1088:149-157. https://doi. org/10.1016/j.jchromb.2018.04.031
29. Azzoni AR, Ribeiro SC, Monteiro GA, Prazeres DMF (2007) The impact of polyadenylation signals on plasmid nuclease-resistance and transgene expression. J Gene Med 9(2007):392-402. https:// doi.org/10.1002/jgm.1031

30. Neto GMN (2018) Desenvolvimento e validação de método para a identificação de micro-organismos metabolicamente ativos em biofilmes de amostras ambientais através da análise de rRNA 16S. PhD Thesis, University of São Paulo, Brazil, pp 53-54. https:// teses.usp.br/teses/disponiveis/42/42132/tde-26032018-164037/en. $\mathrm{php}$

31. Hedden K (1963). Adv Chem Eng. https://doi.org/10.1524/zpch. $1963.36 .3 \quad 4.252$

32. Cussler EL (1997) Diffusion: mass transfer in fluid systems, engineering, 2nd ed, p 580. https://doi.org/10.1017/CBO9780511 805134.010

33. Belhachemi M, Addoun F (2011) Comparative adsorption isotherms and modeling of methylene blue onto activated carbons. Appl Water Sci 1:111-117. https://doi.org/10.1007/ s13201-011-0014-1

34. Sposito G (2008) The chemistry of soils, p 195. https://doi.org/ 10.1017/CBO9781107415324.004.

35. Sposito G (1980) Derivation of the Freundlich equation for ion-exchange reactions in soils. Soil Sci Soc Am J 44:652-654. https://doi.org/10.2136/sssaj1980.03615995004400030045x

36. Müller E (2005) Properties and characterization of high capacity resins for biochromatography. Chem Eng Technol 28:1295-1305. https://doi.org/10.1002/ceat.200500161

37. Tarmann C, Jungbauer A (2008) Adsorption of plasmid DNA on anion exchange chromatography media. J Sep Sci 31(14):26052618. https://doi.org/10.1002/jssc.200700654

38. Wilcox JL, Ahlualia AK, Bevilacqua PC (2011) Charged nucleobases and their potential for RNA catalysis. Acc Chem Res 44:1270-1279. https://doi.org/10.1021/ar2000452

39. Sousa F, Matos T, Prazeres DMF, Queiroz JA (2008) Specific recognition of supercoiled plasmid DNA in arginine affinity chromatography. Anal Biochem 374:432-434. https://doi.org/10.1016/j. ab.2007.11.005

40. Yusufaly TI, Li Y, Singh G, Olson WK (2014) Arginine-phosphate salt bridges between histones and DNA: Intermolecular actuators that control nucleosome architecture. J Chem Phys 141(16):165102. https://doi.org/10.1063/1.4897978

Publisher's Note Springer Nature remains neutral with regard to jurisdictional claims in published maps and institutional affiliations. 